\title{
Marking the End of Direct Speech in Late Latin
}

\author{
Jana Mikulová \\ (Masaryk University, Brno)
}

\begin{abstract}
The present paper examines the marking of the end of direct speech in five selected Late Latin texts. It shows that a range of strategies are employed in the texts, among which it analyses the use of particles, pronouns and participle constructions in greater detail. Although the end of direct speech tended to be signalled, none of the means can be viewed as a routinized marker of the end of direct speech in Late Latin - the particle et 'and' was found 19\% of instances in the examined texts. When an expression was used in a seemingly routine fashion, its higher occurrence was limited to one or two texts and attributed in the present analysis to the author's style. The most frequent expressions identified (the particles et and -que 'and', demonstrative and relative pronouns) do not carry any specific meaning with respect to direct speech but rather fulfil the function of cohesive device. The end of direct speech thus seems to be treated as a mere boundary in the discourse, lacking any specific marking in Late Latin.
\end{abstract}

\section{Keywords}

Late Latin; direct speech; quotation; particles; grammaticalization; quotative markers

\section{Introduction}

The different means used for introducing direct speech have been analysed in many languages (see Güldemann 2008, Vandelanotte 2012, Golato 2000, Deutscher 2011), most recently also in Latin (e.g. Fruyt 2011, Gayno 2015, Sznajder 2015). Within Latin linguistics, scholars often focus on Late Latin since the number of instances of direct speech is higher in that period than in Classical Latin (see Fruyt 2011: p. 693), and the introducer dicens 'saying' increases in frequency and importance. Scholars such as Sznajder (2015: p. 22) and Fruyt (2011: p. 693) point out that this form of the introducer has an important text-organizing function at the beginning of direct speech. The finite verbal forms of dicere or aio 'to say' are also very often used ${ }^{1}$ in Late Latin, while the Classical Latin inquit 'he/she says/said', inserted in direct speech in most cases, in turn decreases in use. Both dicens 'saying' and the finite verbal forms are usually placed before direct speech and so are in opposition to the inserted inquit 'he/she says/said', which points

1 See Mikulová (2015: pp. 130ff.). 
to the importance of marking the beginning of direct speech. If the clearly marked beginning is preferred to enhance text comprehensibility, the question arises whether the end of direct speech is also similarly marked. Although addressed to an extent by Gayno (2015, see below), this question is examined in the present paper in greater detail by investigating more closely the different expressions used immediately after direct speech for marking its end. An attempt is made to systematise the different ways of marking the feature and to ascertain whether some of the forms tend to become routinized in this period, which could suggest the possibility for the process of further grammaticalization in this connection. To this end, five Late Latin texts from the sixth to eighth centuries have been analysed, namely Life of Fathers by Gregory of Tours and Vita Goaris, Vita Wandregiseli, Vita Memorii, and Vitas patrum Emeritensium by different anonymous authors. It is a sample of texts that meet the following criteria: they are of the same genre (Vitae lives of the Saints), within which direct speech is regularly employed; they contain more than a few instances of direct speech; and they date back to a period which was characterized by the decrease in the level of education and the command of Latin, and which had preceded Alcuin's reform of pronunciation and was important for the development of Romance languages. Given these conditions, the tendency to make the text structure clear by a type of marking can be expected to be at play.

The paper is organized as follows: first, the different strategies that are employed for marking the end of direct speech in languages in general and in Latin in particular will be outlined; second, various types of means for this purpose used in the selected texts will be analysed; third, possible developments of a specific marker will be discussed; fourth, the means used in the texts under examination will be compared; and finally, conclusions will be drawn.

\subsection{Strategies of marking the end of direct speech}

The end of direct speech can be marked in different ways, the first of which is the use of a quotative marker. Güldemann (2008: pp. 191-192) categorises quotative markers (in his terminology quotative indexes) into four main groups according to the mutual position of a quotative marker and the direct speech (he uses the term quote): preposed, postposed, circumposed and intraposed quotative markers, suggesting that among these, the most frequent ones are preposed quotative markers, followed by postposed, circumposed and intraposed markers (p. 195). In Late Latin, it is typical to mark the beginning of direct speech, and thus if the end of direct speech is marked, it usually means that direct speech is marked in both boundaries. Such a marking is typical of circumposed quotative markers, which, however, differ from what Güldemann (2008: pp. 201-202) calls a quote frame. While a circumposed quotative marker is basically one marker split into two parts, a quote frame - having seemingly the same structure - is a combination of two independent quotative markers, the preposed and the postposed ones. Moreover, he also mentions the so called tail-head linkage in which direct speech is followed by an expression such as "having saying this..., which takes up the previous speech event merely for the sake of creating text 
cohesion" (p. 195). Regardless of the type of marking, any expression at the end of direct speech is likely to play an important role since it clearly signals a boundary in the text.

Another strategy of marking the end of direct speech consists of using discourse markers. It is well-known that discourse markers are not a clear-cut category but rather a category with fuzzy borderlines and different definitions (see Fraser 1999: p. 938; Diewald 2013: p. 21; Schiffrin 2001: pp. 55-60). In this paper, a broader definition employed by Ghezzi (2014: p. 15) is adopted: “...the term discourse marker is mainly used to refer to elements that index the structure of discourse, functioning as discourse-cohesive devices that stress intra-discourse relations and specify how the message or its content is related to the preceding and following discourse or the extralinguistic situation." An example of this type of a marking of the end of direct speech is provided by Louviot (2013), who examined the use of da in the Middle English poetry, and found that this discourse marker "probably facilitated its correct interpretation by the audience" (p. 388). She (ibid.) shows that this discourse marker followed direct speech in more than $60 \%$ of cases in the examined poems, but also notes that it is a means used not only for signalling the end of direct speech since it can "introduce any narrative section possessed of certain degree of independence and coherence" (p. 388). When it comes to the texts analysed in this paper, the function of discourse markers is often fulfilled by particles that can also be rather difficult to define. For that reason, Rosén (2009: pp. 317-318) suggests describing the functions of these words rather than seeking a universal definition of particles, distinguishing four classes of their functions: "(a) production of textual coherence (by connectors and connective adverbs), (b) discourse organization and communication management, (c) modalization and illocutionary identification, (d) focus marking" (p. 326). She points out (ibid.), however, that the classes a, b on one hand, and the classes $c, d$ on the other "are not strictly separable from each other and are apprehended as partly overlapping”. For the purpose of the present paper, the classes a and b are especially relevant since the particles of these classes can function as discourse markers.

Besides quotative and discourse markers, the end of direct speech can be signalled also by anaphoric expressions or such strategies as the change of the person or character speaking. Alternatively, no marking (zero marking) can be employed. Finally, the end of direct speech can be indicated by a combination of various strategies.

\subsection{Marking of the end of direct speech in Latin}

The marking of the end of direct speech in Latin has been rarely examined, with virtually no studies concerning Classical Latin texts. A few selected Late Latin texts have been recently examined by Gayno (2015: pp. 1-3), who claims that the end of direct speech in this period is most often signalled by a relative pronoun (the so called free relative connection $)^{2}$ or by an ablative absolute, such as his dictis "after these words" in the

2 The free relative connection is defined by Matras \& Bolkestein (2006: p. 222) as follows: “...in this construction, a constituent of the preceding clause, or of an even earlier one, or some text segment, is referred to in a new (subordinate or main) clause by means of the relative pronoun (qui, quae, quod)". 
sentence following direct speech. These instances can be considered examples of tailhead linkage as defined above. Gayno (ibid.) notes that other means can also be employed (e.g. a subordinate clause with the conjunction cum 'when'), or no marking of the end of direct speech at all. Gayno (2015: p. 1) assumes that the tendency to mark the end of direct speech was motivated by the lack of punctuation. Thus, she uses similar arguments as Louviot (see above), concluding that the marking of the boundaries of direct speech aids text comprehension. Gayno's findings about the variety of means found in Late Latin form the basis of the present study, which examines the different expressions identified after direct speech in greater detail.

\section{Marking of the end of direct speech in the examined texts}

As pointed above, the end of direct speech can be indicated by various strategies. The present paper examines solely explicit expressions (and not, for an example, the change of a speaking person), focusing on those means that may be suitable for becoming routinized markers of the end of direct speech. Such a marker is supposed to have a fixed form and not to be too long. Therefore, larger structures, such as clauses following direct speech, are not considered in the present analysis.

Given these conditions of the instances analysed, the expressions found after direct speech were divided into three classes:

- particles which function as discourse markers, ${ }^{3}$

- anaphoric demonstrative pronouns or relative pronouns (in the free relative connection),

- and participle constructions - ablative absolute or the so called conjoined participle.

Each of the expressions, however, is not equally likely to be routinized and/or able to form a kind of the quote frame or tail-head linkage. The most important instances are considered here to be those in which the participle of a verb with the meaning "to say' occurs. None of the participle constructions is a circumposed quotative marker as defined above.

The expressions from different classes can be combined, e.g. et haec dicens 'and saying this' (Greg. Tur. vit. patr. 6, 7) or et his dictis 'and after these words' (V. patr. Emerit. 5, 13). This is common in participle constructions which contain a pronoun or a particle in the majority of cases (always participles with the meaning 'to say'). The co-occurrence of a particle and a demonstrative or relative pronoun was found in one third of the examined instances. The combination of two particles is also possible, but occurred only five times in the dataset.

Apart from the type of expressions used after direct speech, their distribution as per a discourse type following the direct speech has been examined. For this purpose, three basic categories were distinguished:

1. Transition to narration: direct speech is followed by narration.

2. Dialogue: direct speech is followed by a new turn in the dialogue. This category

3 For the sake of brevity, particles with the function of discourse marker are referred to as particles in the present paper. 
contains both "quick" and "slow" exchanges. In "quick" exchanges, the subsequent turns are separated by a few words indicating a change of the speaking person and introducing a new turn (e.g. et ille, Greg. Tur. vit. patr. 'and he'). In "slow" exchanges, the new turn is separated from the previous one by a longer description of some additional circumstance (e. g. Et accedens ad regem dixit, V. Goar. 8 'He approached the king and said'), but the exchange occurs in the same communicative situation.

3. Quotation: direct speech is followed by another coordinated direct speech (mainly a quote from the Bible).

In addition, a few instances of direct speech (12 items in total) have been found to be inserted in another direct speech. These cases are not considered as a separate category here since their function - within another direct speech - is similar to the transition to narration, and therefore were classified within the first category.

\subsection{Expressions occurring at the end of direct speech}

Table 1 below shows all the expressions occurring in the examined texts. The list of particles is based on the list of Late Latin particles by Rosén (2009: pp. 390-393). Only those particles which occurred at least in one of the examined texts and could function as a means of textual coherence or discourse organization (i.e. classes a and $\mathrm{b}$, see above) were included. The first figure in every cell indicates a total number of instances in the individual works. The figures in brackets show the category of a discourse type in which individual particles, pronouns or participle constructions are employed. The first number corresponds to the category "transition to narration", the second one to the category "dialogue", and the last one to the category "quotation". When a particle and a pronoun occurred together, the instance was classified as marked by a particle, since particles are arguably a more specific sign of the end of direct speech than pronouns.

Table 1: Expressions occurring in the examined texts ${ }^{4}$

\begin{tabular}{|c|c|c|c|c|c|c|}
\hline & $\begin{array}{l}\text { Greg. Tur. } \\
\text { vit. patr. }\end{array}$ & V. Goar. & V. Memor. & V. Wandr. & \begin{tabular}{|l} 
V. patr. \\
Emerit.
\end{tabular} & In total \\
\hline \multicolumn{7}{|l|}{ Particles $^{4}$} \\
\hline$a c$ 'and' & & & & & $1(1 / 0 / 0)$ & $1(1 / 0 / 0)$ \\
\hline $\begin{array}{l}\text { at 'but, moreover, } \\
\text { yet' }\end{array}$ & $22(14 / 8 / 0)$ & $1(1 / 0 / 0)$ & $3(2 / 1 / 0)$ & $1(1 / 0 / 0)$ & $5(2 / 3 / 0)$ & $32(20 / 12 / 0)$ \\
\hline
\end{tabular}

4 The translation of particles is only approximate since it is dependent on the context in which the particle appears. 


\begin{tabular}{|c|c|c|c|c|c|c|}
\hline & $\begin{array}{l}\text { Greg. Tur. } \\
\text { vit. patr. }\end{array}$ & V. Goar. & V. Memor. & V. Wandr. & $\begin{array}{l}\text { V. patr. } \\
\text { Emerit. }\end{array}$ & In total \\
\hline $\begin{array}{l}\text { autem 'but, more- } \\
\text { over, on the other } \\
\text { hand' }\end{array}$ & $19(18 / 1 / 0)$ & $1(1 / 0 / 0)$ & $2(1 / 1 / 0)$ & $2(2 / 0 / 0)$ & $2(2 / 0 / 0)$ & $26(24 / 2 / 0)$ \\
\hline $\begin{array}{l}\text { dehinc 'after that, } \\
\text { then' }\end{array}$ & $1(1 / 0 / 0)$ & & & & & $1(1 / 0 / 0)$ \\
\hline $\begin{array}{l}\text { deinde 'after- } \\
\text { wards, then' }\end{array}$ & & & & & $6(6 / 0 / 0)^{5}$ & $6(6 / 0 / 0)$ \\
\hline $\begin{array}{l}\text { denique 'finally, } \\
\text { and then' }\end{array}$ & $3(3 / 0 / 0)$ & & & & & $3(3 / 0 / 0)$ \\
\hline $\begin{array}{l}\text { denuo 'again, then } \\
\text { again' }\end{array}$ & & & & & $2(2 / 0 / 0)$ & $2(2 / 0 / 0)$ \\
\hline enim 'indeed, for' & $11(11 / 0 / 0)$ & & & $1(1 / 0 / 0)$ & & $12(12 / 0 / 0)$ \\
\hline $\begin{array}{l}\text { ergo 'therefore, } \\
\text { then' }\end{array}$ & $8(8 / 0 / 0)$ & & & & & $8(8 / 0 / 0)$ \\
\hline et 'and' & $47(29 / 13 / 5)$ & $7(4 / 1 / 2)$ & $12(8 / 4 / 0)$ & $7(6 / 0 / 1)$ & $14(10 / 4 / 0)$ & $87(57 / 22 / 8)$ \\
\hline $\begin{array}{l}\text { etenim 'and in- } \\
\text { deed, for' }\end{array}$ & & & & $1(1 / 0 / 0)$ & & $1(1 / 0 / 0)$ \\
\hline $\begin{array}{l}\text { ideo 'for that rea- } \\
\text { son, therefore' }\end{array}$ & & $2(1 / 0 / 1)$ & & & & $2(1 / 0 / 1)$ \\
\hline $\begin{array}{l}\text { igitur 'then, there- } \\
\text { fore, accordingly' }\end{array}$ & $3(3 / 0 / 0)$ & $1(1 / 0 / 0)$ & & & $1(1 / 0 / 0)$ & $5(5 / 0 / 0)$ \\
\hline $\begin{array}{l}\text { ita 'in such a way, } \\
\text { so, thus' }\end{array}$ & & & & & $1(1 / 0 / 0)$ & $1(1 / 0 / 0)$ \\
\hline $\begin{array}{l}\text { iterum 'once } \\
\text { more, again' }\end{array}$ & & $1(1 / 0 / 0)$ & $1(1 / 0 / 0)^{6}$ & & & $2(2 / 0 / 0)$ \\
\hline $\begin{array}{l}\text { nam/namque 'for, } \\
\text { but now, on the } \\
\text { other hand' }\end{array}$ & $3(3 / 0 / 0)$ & & & & $1(1 / 0 / 0)$ & $4(4 / 0 / 0)$ \\
\hline $\begin{array}{l}\text { porro 'then, next, } \\
\text { furthermore, } \\
\text { moreover, be- } \\
\text { sides' }\end{array}$ & $1(1 / 0 / 0)^{7}$ & & & $2(2 / 0 / 0)$ & & $3(3 / 0 / 0)$ \\
\hline $\begin{array}{l}\text { protenus 'forward, } \\
\text { farther on, on- } \\
\text { ward' }\end{array}$ & $2(2 / 0 / 0)$ & & & & & $2(2 / 0 / 0)$ \\
\hline -que 'and' & $18(17 / 1 / 0)$ & $9(7 / 1 / 1)$ & & & $9(9 / 0 / 0)$ & $36(33 / 2 / 1)$ \\
\hline $\begin{array}{l}\text { sed 'but, but also, } \\
\text { but even' }\end{array}$ & $9(9 / 0 / 0)$ & & & $1(1 / 0 / 0)$ & & $10(10 / 0 / 0)$ \\
\hline sic 'so, thus' & $2(2 / 0 / 0)$ & & & & & $2(2 / 0 / 0)$ \\
\hline $\begin{array}{l}\text { tandem 'at length, } \\
\text { at last, in the end, } \\
\text { finally' }\end{array}$ & & & & & $2(2 / 0 / 0)$ & $2(2 / 0 / 0)$ \\
\hline
\end{tabular}

5 Three instances of deinde appear in combination (once with $a c$ and twice with tum), and therefore these instances are not included in the total number of items.

6 This instance appears in a combination with $e$, and therefore it is not included in the total number of items.

7 This instance appears in a combination with autem, and therefore it is not included in the total number of items. 


\begin{tabular}{|c|c|c|c|c|c|c|}
\hline & $\begin{array}{l}\text { Greg. Tur. } \\
\text { vit. patr. }\end{array}$ & V. Goar. & V. Memor. & V. Wandr. & $\begin{array}{l}\text { V. patr. } \\
\text { Emerit. }\end{array}$ & In total \\
\hline $\begin{array}{l}\text { tum 'then, at that } \\
\text { time' }\end{array}$ & & & & & $2(2 / 0 / 0)$ & $2(2 / 0 / 0)$ \\
\hline $\begin{array}{l}\text { tunc 'then, at that } \\
\text { time' }\end{array}$ & $14(13 / 1 / 0)$ & $3(1 / 2 / 0)$ & $1(1 / 0 / 0)$ & & $1(1 / 0 / 0)$ & $19(16 / 3 / 0)$ \\
\hline unde 'from which' & $3(3 / 0 / 0)$ & & & & & $3(3 / 0 / 0)$ \\
\hline $\begin{array}{l}\text { vero 'but, though, } \\
\text { however' }\end{array}$ & $10(9 / 1 / 0)$ & $1(0 / 0 / 1)$ & & & $7(4 / 3 / 0)$ & $18(13 / 4 / 1)$ \\
\hline $\begin{array}{l}\text { verumtamen } \\
\text { 'notwithstanding, } \\
\text { however, never- } \\
\text { theless' } \\
\end{array}$ & $1(1 / 0 / 0)$ & & & & & $1(1 / 0 / 0)$ \\
\hline $\begin{array}{l}\text { ends of direct } \\
\text { speech marked } \\
\text { with a particle } \\
\end{array}$ & $177(147 / 25 / 5)$ & $26(17 / 4 / 5)$ & $19(13 / 6 / 0)$ & $15(14 / 0 / 1)$ & $54(44 / 10 / 0)$ & 291 \\
\hline $\begin{array}{l}\text { ends of direct } \\
\text { speech marked } \\
\text { with a particle } \\
\text { (combined par- } \\
\text { ticles have been } \\
\text { subtracted) } \\
\end{array}$ & $176(146 / 25 / 5)$ & $26(17 / 4 / 5)$ & $18(12 / 6 / 0)$ & $15(14 / 0 / 1)$ & $51(41 / 10 / 0)$ & 286 \\
\hline \multicolumn{7}{|l|}{ Pronouns } \\
\hline relative & $38(26 / 12 / 0)$ & $13(6 / 7 / 0)$ & $1(1 / 0 / 0)$ & $2(2 / 0 / 0)$ & $19(17 / 2 / 0)$ & $73(52 / 21 / 0)$ \\
\hline $\begin{array}{l}\text { demonstrative } \\
\text { (hic in most } \\
\text { cases) }\end{array}$ & $21(21 / 0 / 0)$ & $12(12 / 0 / 0)$ & $1(1 / 0 / 0)$ & $2(2 / 0 / 0)$ & $9(8 / 1 / 0)$ & $45(44 / 1 / 0)$ \\
\hline $\begin{array}{l}\text { ends of direct } \\
\text { speech with a pro- } \\
\text { noun }\end{array}$ & $59(47 / 12 / 0)$ & $25(18 / 7 / 0)$ & $2(2 / 0 / 0)$ & $4(4 / 0 / 0)$ & $28(25 / 3 / 0)$ & $118(96 / 22 / 0)$ \\
\hline \multicolumn{7}{|c|}{\begin{tabular}{|l|l} 
Participle constructions \\
\end{tabular}} \\
\hline $\begin{array}{l}\text { participle of a verb } \\
\text { with the meaning } \\
\text { 'to say' } \\
\end{array}$ & $14(14 / 0 / 0)$ & $8(6 / 2 / 0)$ & $1(1 / 0 / 0)$ & $0(0 / 0 / 0)$ & $5(5 / 0 / 0)$ & $28(26 / 2 / 0)$ \\
\hline $\begin{array}{l}\text { participle of an- } \\
\text { other verb }\end{array}$ & $43(41 / 2 / 0)$ & $11(7 / 4 / 0)$ & $4(0 / 4 / 0)$ & $7(7 / 0 / 0)$ & $14(13 / 1 / 0)$ & $79(68 / 11 / 0)$ \\
\hline \begin{tabular}{|l|} 
ends of direct \\
speech with a par- \\
ticiple construction
\end{tabular} & $57(55 / 2 / 0)$ & $19(13 / 6 / 0)$ & $5(1 / 4 / 0)$ & $7(7 / 0 / 0)$ & $19(18 / 1 / 0)$ & $107(94 / 13 / 0)$ \\
\hline \begin{tabular}{|l|} 
participle con- \\
structions with- \\
out any particle or \\
pronoun $^{8}$
\end{tabular} & 2 & 1 & 3 & 3 & 0 & 9 \\
\hline $\begin{array}{l}\text { Ends of direct } \\
\text { speech with } \\
\text { a particle, pro- } \\
\text { noun or participle } \\
\text { construction in } \\
\text { total }\end{array}$ & 237 & 52 & 23 & 22 & 79 & 413 \\
\hline
\end{tabular}

8 Since the participle constructions often contain a pronoun or a particle, they are counted only once, and therefore only the figures of this row are included into the total sum of instances. 


\begin{tabular}{|l|l|l|l|l|l|l|}
\hline & $\begin{array}{l}\text { Greg. Tur. } \\
\text { vit. patr. }\end{array}$ & V. Goar. & V. Memor. & V. Wandr. & $\begin{array}{l}\text { V. patr. } \\
\text { Emerit. }\end{array}$ & In total \\
\hline Others ${ }^{10}$ & 13 & 4 & 3 & 5 & 1 & 26 \\
\hline Zero marking & 13 & 2 & 0 & 1 & 1 & 17 \\
\hline $\begin{array}{l}\text { Ends of direct } \\
\text { speech in total }\end{array}$ & 263 & 58 & 26 & 28 & 81 & 456 \\
\hline
\end{tabular}

The figures show that the most frequently occurring way of marking the end of direct speech in the examined texts is the class of particles, followed by pronouns and the class of participle constructions. It is noteworthy that the participle constructions without any particle or pronoun occurred only in 9 out of 107 instances, and therefore a combination of various types of strategies seems to have been employed.

When the frequency of individual particles, pronouns and participle constructions with the verb 'to say' (i.e. the constructions most likely to become a routinized marker) is compared, the most frequently used expression in all the texts considered together is $e t$ 'and', followed by relative pronouns, demonstrative pronouns, -que 'and', at 'but, moreover, yet', autem 'but, however, yet', participle constructions containing a verb with the meaning 'to say', tunc 'then', vero 'in fact, certainly', enim 'indeed, for', and sed 'but'. The remaining expressions occurred less than ten times.

As regards the distribution among the discourse types following direct speech, none of the expressions can be linked only to one type. Unsurprisingly, the type "quotation" prefers $e t$ 'and', while the type "transition to narration" shows roughly the same usage of the expressions indicated in the previous paragraph. In contrast, there is a difference in the type "dialogue", since demonstrative pronouns are barely used here, and the particle at 'but, moreover, yet' takes the third place in terms of frequency of occurrence. However, the tendency for $e t$ 'and' or relative pronouns remains unchanged even in dialogues. Thus, the discourse type that follows direct speech does not seem to play a decisive role in the choice of an expression at the end of direct speech in Late Latin.

When the use of particles and pronouns is considered, the four most frequent ones have quite a general, non-specific function - they express primarily continuation or refer anaphorically to direct speech, a previously mentioned character or a thing. In contrast, the particles which are supposed to have more specific functions were used less often and distributed unequally among the examined texts. In Late Latin, however, some of these particles can express a mere continuation in a similar manner as et 'and', due to the developments taking place during the first centuries of the Common Era, as shown by Rosén (2009: pp. 394ff.). She provides an example of the particles nam, ergo and enim, which lost their specific functions and meanings and became "tokens of mere transition and adjunction of one sentence, or a chunk of some other size, to another" (p. 397).

9 Sums of the rows of grey colour.

10 The label "others" is employed for those instances that do not belong to any of the established categories. It does not mean, however, that the end of direct speech is not marked at all in the examined texts (the number of unmarked instances is displayed in the subsequent line). For an example, the turn alternation in a dialogue can be signalled by the names of the speaking persons. However, as indicated above, these strategies were not examined in this paper. 
These findings concerning a semantic shift and overlap of some particles point to the fact that the boundaries between individual particles do not need to be so sharp as in Classical Latin (cf. Kroon 1995). Moreover, during the history of Latin "et replaces other particles and sometimes causes their disappearance in the Romance evolutions" (Orlandini \& Poccetti 2014: p. 269). As for the end of direct speech, it can be inferred that at least in some cases, the occurrence of a particle may be more important than the choice of the specific particle from the pool of more or less synonymous expressions. Not all particles have the same function, however; for example, a higher use of at 'but, moreover, yet' in dialogues suggests that the particle at at least partly retains its characteristic identified for Classical Latin by Kroon (1995: pp. 335-350, 362), who claims that at has primarily an interactional function and operates on the interactional level of discourse. ${ }^{11}$

As for the participle constructions, both the ablative absolute and the conjoined participle of various verbs have been identified in the examined texts; for example, et haec dicens $^{12}$ 'and saying this', et his dictis ${ }^{13}$ 'and after saying this / and after these words', haec effatus $^{14}$ 'after saying this', quo haec audiens ${ }^{15}$ 'hearing this', ille vero abiens 'however, when he went away', ${ }^{16}$ respondens autem sanctus Memorius 'but saint Memorius answered', ${ }^{17}$ and quo aperto 'when it (sc. store) was opened'. ${ }^{18}$ As suggested above, those participle constructions that are most likely to become routinized markers of direct speech are those that contain a verb 'to say', are short and have a fixed form, among which et haec (hec) dicens 'and saying this' is the most frequent ( 8 instances) in the examined texts. The overall low number of the instances, however, does not allow for considering this structure a progressive means for marking the end of direct speech.

\subsection{Development of a specialized marker?}

The examination of the five Late Latin texts shows that various expressions appear at the end of direct speech, but none of them seems to be developing into a marker specialized in signalling the end of direct speech in the way dicens marks its beginning. The participle construction et haec (hec) dicens 'and saying this' would seem to be a good choice, but it is not frequently employed (it occurs only in 1,8\% of all the instances). On the other hand, the most frequent expressions (et 'and', relative or demonstrative pronouns) are general means for creating a cohesive text, and therefore occur in many other instances different from the end of direct speech as well. Moreover, et 'and', the most frequent particle,

11 For the definition of the interactional level of discourse, see Kroon (1995: p. 89).

12 Greg. Tur. vit. patr. 6, 7; 10, 3; 19, 1; 20, 3; V. Goar. 7; V. patr. Emerit. 2; 5, 8.

13 V. patr. Emerit. 5, 13.

14 Greg. Tur. vit. patr. 6, 7; 8, 1;20, 2.

15 V. Goar. 7.

16 Greg. Tur. vit. patr. 6, 3.

17 V. Memor. 5.

18 Greg. Tur. vit. patr. 3, 1. 
appears only in $19 \%$ of all the instances. In this respect, et differs from the Middle English particle da, which, even though not used exclusively for marking the end of direct speech, follows $60 \%$ of the instances of direct speech (Louviot 2013: p. 388, see above). Thus, the examined texts show the same characteristics as the Latin Medieval source of one English poem mentioned by Louviot (2013: pp. 389-391), who claims that the tendency to use one discourse marker in the poem cannot come from the Latin source since various expressions (e.g. autem, et, the participle dicens) appear there, and a similar preference for one of them is not observed.

Although there is no evidence that a specific expression is becoming a routinized marker of the end of direct speech in Late Latin, it seems obvious that the overwhelming majority of instances contain some of the expressions considered here, helping the reader to discern the end of direct speech. However, the awareness of the end of direct speech is based not only on the occurrence of these expressions, but also on the interplay of various factors, such as the meaning of the sentence following direct speech, the change of a character or a broader context. In addition, the use of a marking does not imply that the direct speech is considered a text unit different from other ones since these expressions occur throughout the texts as a text-structuring means. Thus, it is likely that the expressions found at the end of direct speech function primarily as markers of a new unit in the text structure and secondarily as markers of the end of direct speech.

\subsection{Comparison of the texts}

When it comes to similarities among the examined texts, a frequent use of 'and' at the end of direct speech can be identified. When et and -que are considered together, 'and' is in fact the most frequent expression occurring in all the texts. It seems reasonable to assume that its prevalence may be at least partially attributed to the biblical influence, since the same holds true for the introducer dicens 'saying', and a glance in the Vulgate suggests that et often starts new text units (see, e.g., Mk 6, 30-56). However, as indicated above, the frequent use of 'and' (especially of et) may be due to the confluence of the spread of the particle $e t$ and the semantic shift of other particles, which makes them more synonymous to $e t$. Moreover, the initial 'and' is a means used across genres and languages, as shown by Dorgeloh (2004), who examined its use in English from a diachronic as well as synchronic perspective.

The texts examined in this paper show also differences, however. For example, with the exception of $e t$, the particles do not seem to be used with the same frequency. This assumption was tested in a sample of particles which included those studied by Kroon (1995) (namely at, autem, enim, nam/namque, tunc, vero) and the particle tunc, found in the texts more than 10 times. Their frequency was estimated in proportion to the length of the text and calculated as the percentage out of all the authorial words in the text (i.e. after subtracting quotes from the Bible or other authors). Instances of particles after direct speech and instances of particles found elsewhere than after direct speech were considered separately. Then, the overall percentage of the particles in individual texts 
was calculated. Although the results cannot be overestimated, they may provide some insight into the differences between the texts (see Table 2).

Table 2: Percentage of the particles in individual texts

\begin{tabular}{|l|l|l|l|l|l|}
\hline & Greg. Tur. vit. patr. & V. Goar. & V. Memor. & V. Wandr. & V. patr. Emerit. \\
\hline $\begin{array}{l}\text { Percentage of the particles } \\
\text { which are not used after direct } \\
\text { speech }\end{array}$ & $1,62 \%$ & $0,55 \%$ & $1,47 \%$ & $0,67 \%$ & $0,88 \%$ \\
\hline $\begin{array}{l}\text { Percentage of the particles } \\
\text { used after direct speech }\end{array}$ & $0,28 \%$ & $0,2 \%$ & $0,63 \%$ & $0,09 \%$ & $0,12 \%$ \\
\hline $\begin{array}{l}\text { Percentage of all the particles } \\
\text { used throughout the texts }\end{array}$ & $1,9 \%$ & $0,75 \%$ & $2,10 \%$ & $0,76 \%$ & $1 \%$ \\
\hline
\end{tabular}

The figures in Table 2 demonstrate that the texts do differ in the frequency of particles both after direct speech and throughout the texts. Liber vitae patrum by Gregory of Tours and Vita Memorii show a higher use of particles than the other texts. Vita Memorii, however, outnumbers Liber vitae patrum in the percentage of particles used at the end of direct speech. Although the remaining texts use particles to a lesser extent, they differ in the ratio of the particles occurring after direct speech to the particles used elsewhere in the text. While Vita Goaris often employs particles after direct speech, Vitas patrum Emeritensium prefers using them out of the context of direct speech, and finally, Vita Wandregiseli does not use particles much either after direct speech or elsewhere. Thus, even though there are differences, there does not seem to be a general tendency for the use of the examined particles after direct speech at the expense of their use in the rest of the texts concerned.

Besides, the texts show at times a preference for an expression which is either absent or rarely used in the other texts. For example, when Gregory of Tours employs the particle -que 'and', he usually adds it to the conjunction cum 'when'. Actually, cumque 'and when' appears in 15 out of 18 instances of -que. The same holds true for Vitas patrum Emeritensium, in which cumque occurs in 7 out of 10 instances. By contrast, cumque is absent from the remaining three texts. Another example can be provided from Vita Goaris, which favours participle constructions, such as et haec dicens 'and saying this', haecque audiente rege 'when the king heard this', quo haec audiens 'when he heard this'. A participle construction occurs in this text in $26 \%$ of the ends of direct speech whereas their frequency is considerably lower (from 12\% to 4\%) in all the remaining texts. A repeated use of some expressions thus seems to be a stylistic preference of an individual author rather than a general tendency. Moreover, even if the author appears to have their favourite expressions, they do not use them exclusively or predominantly in their works.

\section{Conclusions}

This paper examined the marking of the end of direct speech in five Late Latin texts. Contrary to the beginning of direct speech, in which the participle dicens 'saying' came 
to evolve into a specialized marker, the end of direct speech lacks such an expression. The authors under examination seem to signal the end of direct speech by diverse means, such as particles, participle constructions or relative and demonstrative pronouns. In most instances, direct speech is followed by a particle with the meaning 'and', which is not related specifically to the direct speech but rather used throughout the texts. In relation to direct speech, participle constructions containing a verb with the meaning 'to say' could seem to be a more felicitous choice. However, they do not appear in a significant number of cases to qualify for a specialized marker of the end of direct speech. Even though some expressions appear routinely in an individual text, they seem to be attributable to the author's preference rather than to a general tendency, since their repeated use was found to be limited to one or two texts. Furthermore, the choice of an expression is not sensitive to the type of discourse which follows direct speech. The texts under present analyses thus do not provide evidence of the development of any specialized and/or routinized marker used in all the cases or in a discourse type. However, despite the identified differences, the tendency for the use of dicens 'saying' at the beginning and $e t$ at the end of direct speech in the examined texts might have been influenced by the biblical language. In sum, the end of direct speech seems to be one of the boundaries within the text which tends to be marked in some form in Late Latin, albeit not by a specific type of a marking.

\section{Abbreviations}

Greg. Tur. vit. patr.

Gregorius Turonensis, Liber vitae patrum

V. Goar.

Vita Goaris

V. Memor.

Vita Memorii

V. patr. Emerit.

V. Wandr.

Vitas patrum Emeritensium

Vita Wandregiseli

\section{Bibliography}

\section{Primary sources}

Die digitalen Monumenta Germaniae Historica (dMGH) [online]. Reprint. Published by Monumenta Germaniae Historica and Bayerische Staatsbibliothek [Available from: http://www.dmgh.de; accessed 27. 10. 2016].

Jones, E. (Transl.). (1991). Gregory of Tours. Life of the Fathers (with an introd. and notes; $2^{\text {nd }}$ ed.). Liverpool: Liverpool University Press.

Plaetse, R., \& Tombeur, P. (2013). The Electronic Monumenta Germaniae Historica (eMGH) [database]. $13^{\text {th }}$ release. Turnhout: Brepols Publishers. [Available from: http://www.phil.muni.cz/ wlap/; accessed 27. 10. 2016].

Tombeur, P. et al. (2015). Library of Latin Texts - Series A. Centre Traditio Litterarum Occidentalium. 
Turnhout: Brepols. [Available from: http://clt.brepolis.net/llta/Default.aspx; accessed 27. 10. 2016].

\section{Secondary sources}

Deutscher, G. (2011). The Grammaticalization of Quotatives. In H. Narrog, \& B. Heine (Eds.), The Oxford Handbook of Grammaticalization. (pp. 646-655). New York: Oxford University Press.

Diewald, G. (2013). "Same same but different" - Modal particles, discourse markers and the art (and purpose) of categorization. In P. Pietrandrea, B. Cornillie, \& L. Degand (Eds.), Discourse Markers and Modal Particles: Categorization and Description (pp. 19-45). Amsterdam: John Benjamins.

Dorgeloh, H. (2004). Conjunction in sentence and discourse: sentence initial and and discourse structure. Journal of Pragmatics, 36(10), 1761-1779. [DOI: 10.1016/j.pragma.2004.04.004].

Fraser, B. (1999). What are discourse markers? Journal of Pragmatics, 31(7), 931-952.

Fruyt, M. (2011). Grammaticalization in Latin. In P. Baldi, \& P. Cuzzolin (Eds.), New Perspectives on Historical Latin Syntax. Vol. 4: Complex Sentences, Grammaticalization, Typology (pp. 661-864). Berlin: Walter de Gruyter.

Gayno, M. (2015). Les modalités d'insertion du discours direct en latin tardif: bornage et redondance. Revue de Linguistique Latine du Centre Alfred Ernout De Lingua Latina, 10(2). [Retrieved 27. 10. 2016 from http://www.paris-sorbonne.fr/IMG/pdf/DLL_11_M-Gayno.pdf].

Ghezzi, Ch. (2014). The development of discourse and pragmatic markers. In Ch. Ghezzi, \& P. Molinelli (Eds.), Discourse and pragmatic markers from Latin to the Romance languages (pp. 10-26). Oxford: Oxford University Press.

Golato, A. (2000). An innovative German quotative for reporting on embodied actions: Und ich so/und er so 'and I'm like/and he's like'. Journal of Pragmatics, 32(1), 29-54. [DOI: 10.1016/ S0378-2166(99)00030-2].

Güldemann, T. (2008). Quotative Indexes in African Languages: A Synchronic and Diachronic Survey. Berlin-New York: Mouton de Gruyter.

Kroon, C. (1995). Discourse particles in Latin. A study of nam, enim, autem, vero and at. Amsterdam: J. C. Gieben.

Louviot, E. (2013). Transitions from Direct Speech to Narration in Old English Poetry. Neophilologus, 97, 383-393. [DOI: 10.1007/s11061-012-9312-6].

Matras, Y., \& Bolkestein, A. M. (2006). Deixis and anaphora: Some case studies. In G. Bernini, \& M. L. Schwartz (Eds.), Pragmatic Organization of Discourse in the Languages of Europe (pp. 215-254). Berlin-New York: Mouton de Gruyter.

Mikulová, J. (2015). Verbs introducing direct speech in Late Latin texts. Graeco-Latina Brunensia, 20(2), 123-143.

Orlandini, A., \& Poccetti, P. (2014). Polyfunctionality and transcategoriality of coordinating particles in Latin and in other ancient languages. Journal of Latin Linguistics, 13(2), 267-278.

Rosén, H. (2009). Coherence, sentence modification, and sentence-part modification - the contribution of particles. In P. Baldi, \& P. Cuzzolin (Eds.), New Perspectives on Historical Latin Syntax. Vol. 1: Syntax of the Sentence (pp. 317-442). Berlin-New York: Mouton de Gruyter.

Schiffrin, D. (2001). Discourse Markers: Language, Meaning, and Context. In D. Schiffrin, D. Tannen, \& H. E. Hamilton (Eds.), The Handbook of Discourse Analysis (pp. 54-75). Oxford: Blackwell. 
Sznajder, L. (2015). Segments introducteurs de discours direct et repérages énonciatifs en latin biblique: éléments pour une étude diastratique et diachronique. Revue de Linguistique Latine du Centre Alfred Ernout De Lingua Latina, 10(2). [Retrieved 27. 10. 2016 from http://www.parissorbonne.fr/IMG/pdf/DLL11_SZNAJDER.pdf].

Vandelanotte, L. (2012). Quotative go and be like: Grammar and grammaticalization. In I. van Alphen, \& I. Buchstaller (Eds.), Quotative: Cross-Linguistic and Cross-Disciplinary Perspectives (pp. 173-202). Amsterdam: John Benjamins.

Mgr. Jana Mikulová, Ph.D. / jmikulova@gmail.com

Department of Classical Studies

Masaryk University, Faculty of Arts

Arna Nováka 1, 60200 Brno, Czech Republic 